\title{
Kecerdasan Emosional dan Perilaku Kewarganegaraan Organisasi pada Pegawai Badan Kepegawaian Daerah
}

\author{
Sukma Nugraha \\ Faculty of Entrepreneurship, Universitas Garut \\ Jalan Jati 42 B Garut, 44151, Indonesia \\ sukmanugraha@uniga.ac.id
}

\begin{abstract}
Abstrak- Permasalahan yang ada di dalam organisasi akan mengahambat tujuan organisasi, maka organisasi perlu menciptakan strategi untuk meningkatkan perilaku kewargaan organisasi dengan upaya memperbaiki dan meningkatkan kecerdasan emosional dan perilaku kewarganegaraan organisasi. Penelitian ini bertujuan untuk mengetahui pengaruh kecerdasan emosional terhadap perilaku kewarganegaraan organisasi. Objek yang menjadi unit analisis dalam penelitian ini adalah Badan Kepegawaian Daerah. Variabel dalam penelitian ini adalah kecerdasan emosional dan kepuasan kerja. Jenis penelitian yang digunakan adalah deskriptif. Metode yang digunakan adalah explanatory survey dengan teknik sampel yaitu sampel tidak jenuh dengan jumlah sampel 103 responden. Teknik analisa data yang digunakan adalah regresi berganda dengan alat bantu software komputer Statistical Product for Service Solutions (SPSS). Hasil temuan dalam penelitian ini menunjukkan bahwa gambaran kecerdasan emosional dalam kategori baik, gambaran kepuasan kerja dalam kategori tinggi.
\end{abstract}

Kata Kunci- Kecerdasan Emosional, Kepuasan Kerja

\section{PENDAHULUAN}

Perilaku setiap individu pasti berbeda-beda sehingga dalam suatu organisasi pasti akan dipengaruhi oleh setiap individu yang ada di dalamnya. Jika dalam suatu organisasi tidak memiliki satu visi dan misi yang sama, maka organisasi yang ada tersebut tidak akan efektif, karena organisasi akan efektif jika setiap individu yang ada dalam satu kelompok yang membentuk organisasi tidak mementingkan tujuan mereka masing-masing. [1]. Kecerdasan emosional adalah kemampuan untuk mengidentifikasi, mewujudkan perasaan emosi seseorang, dan menerapkannya untuk mengelola hubungan diri sendiri dengan orang lain sehingga membedakan dengan orang lain. Hal ini menunjukkan pentingnya kecerdasan emosional untuk mengelola pekerjaan secara efektif [2]. Kecerdasan emosional menggambarkan kemampuan, kapasitas, keterampilan, atau, dalam kasus model kecerdasan emosional sifatnya, kemampuan besar yang dapat dirasakan untuk mengidentifikasi, menilai, mengelola dan mengendalikan emosi diri sendiri, orang lain, dan kelompok. [3]. Kecerdasan emosional dapat membantu individu untuk memenuhi tuntutan masyarakat dan memberikan rasa kepuasan diri, hal ini mengintegrasikan kemampuan individu dengan tuntutan sosial dan organisasi. [4]. Bukti menunjukkan bahwa individu yang tinggi dalam kecerdasan emosional lebih mungkin untuk melakukan tingkat yang lebih tinggi dari hasil kerja. [5]. Penelitian di bidang human resource menunjukkan hubungan antara kecerdasan emosional dan variabel lain, bahwa kecerdasan emosional memiliki peran penting dalam pertumbuhan organisasi. [4].

Kepuasan kerja merupakan faktor yang digunakan untuk mengatasi permasalahan pada perilaku kewargaan organisasi, yang menunjukkan hubungan positif dengan perilaku kewargaan organisasi. [6]. Kepuasan terjadi ketika ada kecocokan antara harapan individu dari pekerjaannya. Kepuasan kerja dikonseptualisasikan Mumford (1991) dalam dua bagian, pertama adanya kesesuaian antara organisasi dan harapam pegawai, kedua harapan pegawai dan imbalan yang didapat sesuai hasil kerja. Kepuasan kerja merupakan reaksi mental dan emosional terhadap pekerjaannya yang positif. [7]. Laporan tahunan Badan Kepegawaian Daerah Provinsi Jawa Barat telah menunjukkan salah satu perilaku kewargaan organisasi yang belum maksimal, upaya yang harus dilakukan oleh organisasi dengan cara meningkatkan kecerdasan 
emosional dan kepuasan kerja, sehingga pegawai merasa nyaman dan mempunyai loyalitas yang tinggi terhadap organisasi. Solusi dari kepuasan kerja diungkapkan dalam penelitian yang dilakukan oleh Hassanreza Zeinabadi (2010) menyatakan bahwa kepuasan kerja berhubungan positif dengan perilaku kewargaan organisasi, pegawai yang puas dari pekerjaannya akan membalas perilaku positif dan memberikan umpan balik yang positif terhadap organisasi [6], strategi yang dilakukan organisasi untuk meningkatkan kepuasan kerja karyawan salah satunya dengan memberikan kompensasi, reward, rekreasi bersama, maka secara tidak langsung pegawai akan merasa nyaman dan timbul rasa peduli untuk memajukan organisasi. Hasil wawancara yang dilakukan oleh salah satu Bagian Kepegawaian dengan Bapak Kamal di Badan Kepegawaian Daerah Provinsi Jawa Barat yaitu belum ada kegiatan untuk meningkatkan kecerdasan emosional pegawai, sedangkan untuk meningkatkan kepuasan kerja pegawai dari pemberian kompensasi dan reward sudah terlaksana, namun kegiatan rekreasi bersama tidak ada. Tujuan penelitian ini untuk memperoleh temuan mengenai pengaruh kecerdasan emosional terhadap perilaku kewarganegaraan organisasi.

\section{METODE}

Penelitian ini menggunakan pendekatan perilaku organisasi, khususnya mengenai kecerdasan emosional dan kepuasan kerja. Adapun yang menjadi objek penelitian sebagai variabel bebas (eksogen) adalah kecerdasan emosional (X). Objek penelitian yang menjadi variabel terikat (endogen) adalah perilaku kewarganegaraan organisasi (Y). Objek yang dijadikan responden dalam penelitian ini adalah pegawai di Badan Kepegawaian Daerah. Penelitian menggunakan metode cross sectional metodh, informasi diambil dari sebagian populasi kemudian dikumpulkan langsung dari kejadian secara empirik dengan tujuan mengetahui pendapat dari sebagian populasi terhadap objek yang sedang diteliti di lapangan. Berdasarkan variabel-variabel yang diteliti maka jenis penelitian ini adalah penelitian verifikatif. Penelitian ini akan diuji apakah kecerdasan emosional dan kepuasan kerja berpengaruh terhadap perilaku kewargaan organisasi pada Badan Kepegawaian Daerah. Jenis data yang digunakan dalam penelitian ini adalah data primer dan data sekunder. Sumber data penelitian merupakan sumber-sumber dimana data yang diperlukan untuk membahas suatu masalah penelitian diperoleh secara langsung (data primer) maupun tidak langsung (data sekunder).
Populasi dalam penelitian ini adalah pegawai Badan Kepegawaian Daerah.

\section{TABEL 1 \\ POPULASI PENELITIAN}

\begin{tabular}{lll}
\hline No & Nama Bidang & $\begin{array}{l}\text { Jumlah } \\
\text { Pegawai }\end{array}$ \\
\hline 1 & $\begin{array}{l}\text { Bidang Kesekertariatan } \\
\text { Bidang Mutasi dan }\end{array}$ & 43 \\
2 & Administrasi \\
& $\begin{array}{l}\text { Kepegawaian } \\
\text { Bidang Pengadaan dan } 18\end{array}$ \\
& $\begin{array}{l}\text { Informasi Kepegawaian } \\
\text { Bidang Pengembangan } 18 \\
\text { Karir Kesahteraan dan } \\
\text { Bidang Kesejaht } \\
\text { Disiplin }\end{array}$ \\
\hline & Jumlah \\
\hline
\end{tabular}

Sumber: Bagian Kepegawaian dan Umum BKD

Dari populasi yang telah ditentukan, dalam mempermudahkan melakukan penelitian diperlukan sampel penelitian yang berguna ketika populasi yang diteliti berjumlah besar, dalam artian sampel tersebut harus representatif. Jumlah pegawai Badan Kepegawaian Daerah Provinsi Jawa Barat yaitu sebesar 138 orang pegawai, maka ditarik sampel yang dirumuskan di bawah ini.

Keterangan:

$$
\mathrm{n}=\frac{N}{1+N e^{2}}
$$

$\mathrm{n}$ = Ukuran Sampel

$\mathrm{N}$ = Ukuran Populasi

$\mathrm{e}=$ Kelonggaran ketidaktelitian karena kesalahan sampel yang ditolerir $(e=0,05)$

Berdasarkan rumus diatas maka dapat diukur besarnya sampel yaitu sebagai berikut:

$$
\begin{gathered}
\mathrm{n}=\frac{138}{1+\left(138 x(0,05)^{2}\right)} \\
\mathrm{n}=\frac{138}{1,345} \\
\mathrm{n}=102,6 \approx 103 \text { responden }
\end{gathered}
$$

Berdasarkan hasil perhitungan diatas, yang dibuat dengan tingkat kesalahan sebesar 5\% diperoleh jumlah sampel untuk pegawai Badan Kepegawaian Daerah Provinsi Jawa Barat, maka sampel secara keseluruhan sebanyak 103 orang. Dari sampel di atas, maka ukuran sampel sebaran 103 responden akan dihitung secara proposional sehingga sebaran sampel penelitian dengan menggunakan rumus menurut (Riduwan, 2010)

$$
\mathrm{Ni}=\mathrm{n}\left[\frac{N i}{N}\right] \times \mathrm{n}
$$


Keterangan:

$\mathrm{ni}=$ Jumlah sampel menurut stratum

$\mathrm{n}=$ Jumlah sampel seluruhnya

$\mathrm{Ni}=$ Jumlah populasi

$\mathrm{N}=$ Jumlah populasi seluruhnya

Dengan menggunakan rumus di atas, maka dapat diperoleh jumlah sampel di setiap divisi pada Badan Kepegawaian Daerah Provinsi Jawa Barat sebagai berikut.

1. Bidang Kesekertariatan

$$
=43 / 138 \times 103=32
$$

2. Bidang Mutasi dan Administrasi Kepegawaian $=24 / 138 \times 103=18$

3. Bidang Pengadaan dan Informasi Kepegawaian $=18 / 138 \times 103=13$

4. Bidang Pengembangan Karir

$$
=18 / 138 \times 103=13
$$

5. Bidang Kesejahteraan dan Disiplin $=35 / 138 \times 103=27$

TABEL 2

SEBARAN SAMPEL PENELITIAN

\begin{tabular}{llll}
\hline No & Nama Bidang & Sampel \\
\hline 1 & Bidang Kesekertariatan & 32 \\
\hline 2 & Bidang Mutasi dan & 18 \\
& Administrasi Kepegawaian \\
\hline 3 & Bidang Pengadaan dan & 13 \\
& $\begin{array}{l}\text { Informasi Kepegawaian } \\
4\end{array}$ & $\begin{array}{l}\text { Bidang Pengembangan Karir } \\
\text { Bidang Kesejahteraan dan } \\
5 \\
\text { Disiplin }\end{array}$ \\
\hline & Jumlah & 103 \\
\hline
\end{tabular}

Sumber: Bagian Kepegawaian dan Umum BKD

\section{HASIL DAN PEMBAHASAN}

Hasil Pengujian Verifikatif

Uji Asumsi Klasik

Sebelum melakukan evaluasi terhadap model pengukuran dalam regresi linier berganda mengenai pengaruh kecerdasan emosional dan kepuasan kerja terhadap perilaku kewargaan organisasi, perlu dilakukan uji asumsi klasik yang dilakukan dalam penelitian ini.

Uji Normalitas

Pengujian ini dimaksudkan untuk mengetahui apakah dalam model regresi, variabel pengganggu atau residual mempunyai distribusi normal atau tidak. Uji normalitas dapat dilakukan dengan menggunakan uji one sample kolmogrov-smirnov test, uji normalitas dilakukan dengan menggunakan SPSS (Statistical
Product and Service) 22.0 for windows. Output uji normalitas ini dapat dilihat sebagai berikut:

1. Asymp. Sig >0,05, maka data berdistribusi normal

2. Asymp. Sig < 0,05, maka data tidak

berdistribusi normal

Berdasarkan hasil pengujian normalitas dalam penelitian ini dapat terlihat pada tabel dibawah ini :

TABEL 3

HASIL UJI NORMALITAS

One-Sample Kolmogorov-Smirnov Test

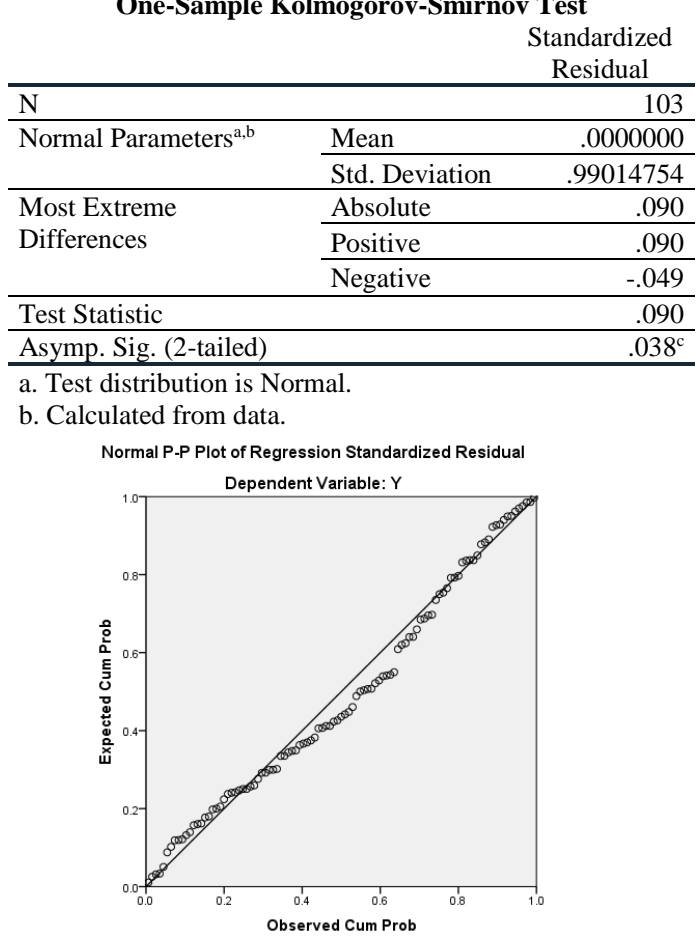

\section{GAMBAR 1 \\ OUTPUT UJI NORMALITAS}

Pada Gambar 1 tersebut menunjukkan bahwa data menyebar sekitar garis diagonal dan mengikuti arah diagonal, maka regresi tersebut dapat disimpulkan populasi memenuhi asumsi berdistribusi normal. Selain itu untuk lebih memperkuat bukti bahwa hasil penelitian tersebut berdistribusi normal atau tidak, maka peneliti melakukan pengujian normalitas menggunakan Kolmogorov-Smirnov Test. Data akan berdistribusi secara normal jika nilai probabilitas yang diharapkan adalah sama dengan nilai probabilitas pengamatan. Pada grafik Plots, kesamaan antara nilai porbabilitas harapan dan probabilitas pengamatan ditunjukan dengan garis diagonal yang merupakan perpotongan antara garis probabilitas harapan dan probabilitas diagonal. 
Uji Heteroskedastisitas

Uji heteroskedastisitas bertujuan untuk menguji apakah dalam model regresi terjadi ketidaksamaan variance dari residual satu ke pengamatan yang lain. Berdasarkan hasil pengujian heteroskedastisitas dalam penelitian ini dapat terlihat pada gambar dibawah ini:

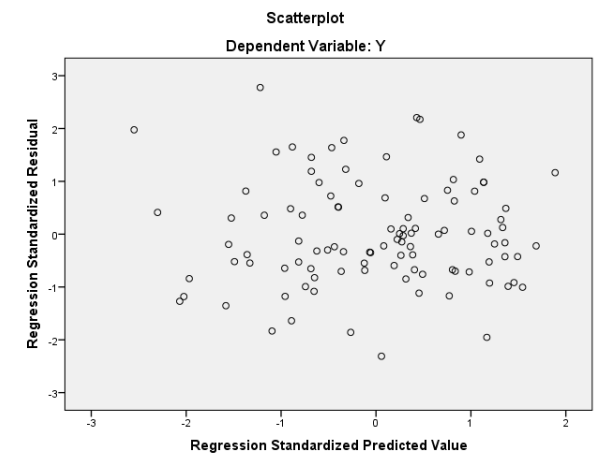

GAMBAR 2

\section{OUTPUT UJI HETEROSKEDASTISITAS}

Berdasarkan hasil dari scatter plot pada gambar 2 terlihat bahwa plot yang terbentuk tidak memiliki pola yang jelas, serta titik-titik menyebar di atas dan dibawah angka 0 pada sumbu Y, maka dapat dikatakan tidak terjadi heteroskedastisitas.

\section{Uji Multikoleniaritas}

Uji multikoleniaritas bertujuan untuk menguji apakah model regresi ditemukan adanya korelasi antar variabel bebas atau independen. Berdasarkan hasil pengujian multikolonieritas dalam penelitian ini dapat terlihat pada tabel dibawah ini:

\section{TABEL 4}

HASIL UJI MULTIKOLONIERITAS

\begin{tabular}{|c|c|c|c|c|c|c|c|}
\hline \multicolumn{8}{|c|}{ Coefficients $^{\mathrm{a}}$} \\
\hline \multirow[b]{2}{*}{ Model } & $\begin{array}{r}\text { Unstan } \\
\text { e } \\
\text { Coeffi }\end{array}$ & $\begin{array}{l}\text { dardiz } \\
\text { cients } \\
\end{array}$ & $\begin{array}{c}\text { Standardiz } \\
\text { ed } \\
\text { Coefficient } \\
\text { s } \\
\end{array}$ & \multicolumn{4}{|c|}{$\begin{array}{c}\text { Collinearity } \\
\text { Statistics }\end{array}$} \\
\hline & $\mathrm{B}$ & $\begin{array}{l}\text { Std. } \\
\text { Error }\end{array}$ & Beta & $\mathrm{t}$ & $\begin{array}{c}\text { Sig } \\
.\end{array}$ & $\begin{array}{c}\text { Toleranc } \\
\mathrm{e}\end{array}$ & VIF \\
\hline 1 (Constant & $\begin{array}{r}42.80 \\
3 \\
\end{array}$ & 7.788 & & $\begin{array}{r}5.49 \\
6 \\
\end{array}$ & $\begin{array}{r}.00 \\
0 \\
\end{array}$ & & \\
\hline $\begin{array}{l}\text { Kecerdasa } \\
\mathrm{n} \\
\text { Emosiona } \\
1\end{array}$ & .392 & .097 & .337 & $\begin{array}{r}4.03 \\
8\end{array}$ & $\begin{array}{r}.00 \\
0\end{array}$ & .719 & $\begin{array}{r}1.39 \\
1\end{array}$ \\
\hline
\end{tabular}

Berdasarkan Tabel 4 di atas dapat dilihat bahwa model regresi tidak mengalami gangguan multikolinieritas. Hal ini tampak pada nilai tolerance masing-masing variabel lebih besar dari 10 persen $(0,1)$. Hasil perhitungan VIF juga menunjukkan bahwa nilai VIF masing-masing variabel kurang dari 10. Jadi dapat disimpulkan bahwa tidak ada multikolinieritas antar variabel independent dalam model regresi tersebut.

\section{Koefisien Determinasi}

Untuk mengetahui besarnya persentase pengaruh $\mathrm{X}_{1}$ dan $\mathrm{X}_{2}$ terhadap $\mathrm{Y}$, maka digunakan rumus koefisien determinasi sebagai berikut.

$$
\mathrm{KD}=\mathrm{r}^{2} \times 100 \%
$$

Keterangan :

$\mathrm{r}^{2}=$ koefisien korelasi ( $R$ square)

Berikut adalah hasil perhitungan koefisien determinasi dari $\mathrm{X}_{1}$ terhadap $\mathrm{Y}$ :

TABEL 5

KOEFISIEN DETERMINASI KECERDASAN EMOSIONAL TERHADAP PERILAKU KEWARGAAN ORGANISASI

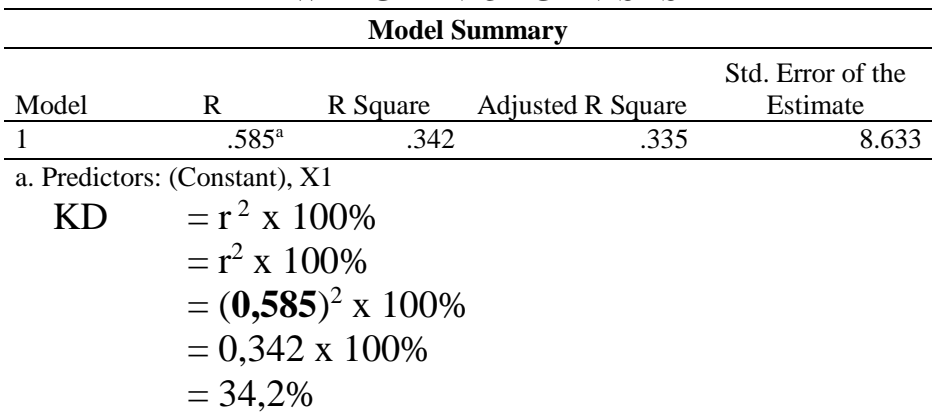

Angka koefisien korelasi (R) sebesar 0,585. Hal ini berarti bahwa hubungan antar kecerdasan emosional dengan perilaku kewargaan organisasi sebesar 0,585. Dari angka tersebut jika diinterpretasikan dapat diambil kesimpulan bahwa hubungan antara variabel kecerdasan emosional dengan variable perilaku kewargaan organisasi adalah sedang/cukup kuat. Dari hasil penghitungan koefisien determinasi untuk kecerdasan emosional dengan perilaku kewargaan organisasi adalah $34,2 \%$. Dengan kata lain kecerdasan emosional dipengaruhi perilaku kewargaan organisasi sebesar 34,2\% sedangkan $65,8 \%$ dipengaruhi oleh faktor-faktor lainnya diluar kecerdasan emosional dan perilaku kewargaan organisasi.

Pengaruh Kecerdasan Emosional Terhadap Perilaku Kewargaan Organisasi

Berdasarkan hasil penelitian yang bersifat empiris mengenai pengaruh kecerdasan emosional dan kepuasan kerja terhadap perilaku kewargaan organisasi pada pegawai Badan Kepegawaian Daerah Provinsi Jawa Barat, dihasilkan temuan bahwa kepuasan kerja dengan perilaku kewargaan organisasi. Hal tersebut ditunjukkan dengan besarnya Fhitung 
yang jauh lebih besar dari Ftabel $(49,060>3,09)$ yang menyebabkan Ho ditolak. Artinya kecerdasan emosional dan kepuasan kerja secara bersama-sama merupakan penjelas yang signifikan terhadap perilaku kewargaan organisasi. Hasil uji-t pengaruh kecerdasan emosional terhadap perilaku kewargaan organisasi dengan SPSS diperoleh nilai $t_{\text {hitung }}=4,038$ dengan tingkat signifikansi 0,000. Dengan menggunakan batas signifikansi 0.05 , nilai signifikansi tersebut berada di bawah $5 \%$ dan $\mathrm{t}_{\text {hitung }}$ sebesar 4,038>t $>\mathrm{t}_{\text {tabel }}$ sebesar $1.983(\mathrm{df}=103-3=100, \alpha=5 \%)$. Maka kecerdasan emosional berpengaruh positif dan signifikan terhadap perilaku kewargaan organisasi. Dengan besarnya pengaruh kecerdasan emosional terhadap perilaku kewargaan organisasi adalah sebesar 34,2\%.

Kepribadian merupakan salah satu sumber dari afek individu yang dirasakan akan mempengaruhi perilakunya di tempat kerja melalui kemampuan mengelola emosi. Seorang pegawai akan merasakan suasana hati yang baik ketika memandang orang lain atau peristiwa dengan cara yang lebih positif, hal ini akan membuat orang merasa lebih optimis tentang kemampuannya untuk mencapai tujuan, meningkatkan kreativitas, keterampilan mengambil keputusan, serta membuat orang tersebut menjadi suka membantu rekan kerjanya. [8]. Salah satu faktor dari dalam individu yang berpengaruh terhadap perilaku kewargaan organisasi adalah kepribadian dan afek positif pegawai (kecerdasan emosional). Individu yang memiliki kestabilan emosi mampu mentolerir ketidaknyamanan dan tidak mengeluh terhadap kesalahan-kesalahan kecil pihak manajemen yang terjadi di tempat kerja. Adanya hubungan antara dimensi lima kepribadian (big five personality) terhadap perilaku kewargaan organisasi. Dimensi kepribadian seperti conscientiousness mempunyai pengaruh penting dalam kemunculan perilaku kewargaan organisasi. [9].

\section{KESIMPULAN}

Berdasarkan pembahasan teori, hasil penelitian, dan pengujian analisis regresi linear berganda yang dilakukan mengenai pengaruh kecerdasan emosional dan kepuasan kerja terhadap perilaku kewargaan organisasi pada Badan Kepegawaian Daerah dapat disimpulkan bahwa hasil penelitian menyatakan bahwa, kecerdasan emosional berpengaruh positif signifikan terhadap perilaku kewargaan organisasi pegawai pada Badan Kepegawaian Daerah Provinsi Jawa Barat di Bandung, dengan besarnya pengaruh kecerdasan emosional terhadap perilaku kewargaan organisasi sebesar $34,2 \%$ pada tingkat pengaruh kategori baik. Hal ini menunjukkan bahwa semakin baik dalam perilaku kecerdasan emosional pegawai, maka akan semakin baik pula perilaku kewargaan organisasi pegawai terhadap organisasi. Hasil penelitian menyatakan bahwa kecerdasan emosional berpengaruh terhadap perilaku kewargaan organisasi, maka penulis merekomendasikan kepada organisasi dan pimpinan untuk meningkatkan kecerdasan emosional pegawai dengan mengadakan kegiatan dan pelatihan maupun seminar yang dapat mempengaruhi pegawai untuk bersikap seperti mendengarkan orang lain dengan pikiran terbuka, menerima apa yang dikatakan orang lain, mengurangi stress dengan rekreasi bersama, berkomunikasi dengan baik antar pegawai, rekan kerja, dan pimpinan dan percaya terhadap kemampuan diri. Sehingga pegawai mampu menjadi warga organisasi yang baik.

\section{REFERENSI}

[1] A. A. Pooja, D. De Clercq, and I.

Belausteguigoitia, "Job Stressors and Organizational Citizenship Behavior: The Roles of Organizational Commitment and Social Interaction," 2016.

[2] K. Heidarzadeh Hanzaee and M. Mirvaisi, “A survey on impact of emotional intelligence, organizational citizenship behaviors and job satisfaction on employees' performance in Iranian hotel industry," Manag. Sci. Lett., vol. 3, no. 5, pp. 1395-1402, 2013.

[3] A. Ealias and J. George, "Emotional Intelligence and Job Satisfaction: A Correlational study," Commer. Behav. Sci., vol. 1, no. 4, pp. 37-42, 2012.

[4] M. W. Dde, A. Nagar, and T. Nadu, "Management Influence of Emotional Intelligence on OCB of it Executives Karthikeyan, S Arulkumar, S ABSTRACT Research Scholar, Bharathiar University, Coimbatore, Tamil Nadu . KEYWORDS : Emotional Intelligence ( EI ), Organizational Citizenship Behavio," no. 7, pp. 171-173, 2015.

[5] A. H. Sabahi and N. S. Dashti, "Management Science Letters," vol. 6, pp. 475-480, 2016.

[6] H. Zeinabadi, "Job satisfaction and organizational commitment as antecedents of Organizational Citizenship Behavior ( OCB ) of teachers," vol. 5, pp. 998-1003, 2010. 
[7] G. Mathur, A Systematic Guide from Research, no. October. 2016.

[8] D. Goleman, Goleman 2005.pdf. Jakarta, 2005.

[9] Robbins \& Judge, ORGANIZATIONAL BEHAVIOR. 2015. 